\title{
Nano-polyplex based on oleoyl-carboxymethy-chitosan (OCMCS) and hyaluronic acid for oral gene vaccine delivery
}

Ya Liu*, Fang-Qin Wang, Zeana Shah, Xiao-Jie Cheng, Ming Kong, Chao

Feng, Xi-Guang Chen*

College of Marine Life Science, Ocean University of China, Qingdao, 266003, P.R. China

*Corresponding authors: Ya Liu, E-mail: yaliu@ouc.edu.cn; Xi Guang Chen, E-mail: xgchen@ouc.edu.cn

College of Marine Life Science

Ocean University of China

$5^{\#}$ Yushan Road, Qingdao, 266003, China

Tel/Fax.: 86-0532-82032586 


\begin{abstract}
Here we described nano-polyplexes (NPs) made of oleoyl-carboxymethy-chitosan (OCMCS)/hyaluronic acid (HA) as novel potential carriers for oral gene vaccines delivery. Aerolysin gene (aerA) of Aeromonas hydrophila as microbial antigen was efficiently loaded to form OCMCS-HA/aerA (OHA) NPs. OHA NPs performed the optimal parameters, i.e. smallest $(154.5 \pm 9.4 \mathrm{~nm})$, positive charged $(+7.9 \pm 0.5 \mathrm{mV})$ and monodispersed system with the N/P ratio of 5 and OCMCS/HA weight ratio of 4 . Upon the introduction of HA, OHA NPs was beneficial for the DNA release in intestinal environments in comparison to OA NPs. The mean fluorescence intensity detected in Caco-2 cells incubated with OHA NPs was about 2.5-fold higher than that of OA NPs; however, it decreased significantly in the presence of excess free HA. The OHA NPs and OA NPs decreased the transepithelial electric resistance (TEER) of Caco-2 monolayers obviously and induced increasing the apparent permeability coefficient $\left(P_{\text {app }}\right)$ of DNA by 5.45-6.09 folds compared with free DNA. Significantly higher $(\mathrm{P}<0.05)$ antigen-specific antibodies were detected in serum after orally immunized with OHA NPs than that immunized with OA NPs and DNA alone in carps. These results enable the OHA NPs might resolve challenges arising from gastrointestinal damage to gene antigens, and offer a approach applicable for oral vaccination.
\end{abstract}

Key words: Nano-polyplex, OCMCS, HA, gene vaccine, oral delivery 


\section{1、Introduction}

Aeromonas hydrophila is a ubiquitous bacterial pathogen, which caused infection and several diseases like hemorrhagic septicemia, fin and tail rot in fish, especially carps $[1,2]$. The pathogenicity of $A$. hydrophila appeared to involve several extracellular products (ECPs) including aerolysin, hemolysin, enterotoxin, acetylcholinesterase, as well as a surface array protein layer [3,4]. Carp farming has become a key industry in recent decades over the world. Regarding intensive culture system for carp, boosting the immunity system of carp against stressful circumstances was a good alternative $[5,6]$.

Vaccine strategies were sought-after because of their low toxicity and success in ameliorating serious diseases [7-9]. First generation whole-cell, and second generation acellular, vaccines both have drawbacks such as side effects and lacking durability [10]. The vaccines were also limited in practical application for the intensive fishing industry because of immunization route and bad effectiveness [11,12]. To date, oral vaccination based on antigen (non-virulent peptides, proteins or DNA) offered some obvious advantages over parenteral injection routes, for example, the non-invasive nature of this approach, ease of administration and low cost [13-15].

Oral delivery of oral vaccination in fish was encountered to the three major barriers, namely the enzymatic barriers sourced from the host luminal and membrane bound enzymes $[16,17]$, the immunological cells present within both the enterocytes and underlying connective tissue $[18,19]$, and the physical barrier of the epithelial cells [20, 21]. Many strategies have been developed to enhance oral bioactive compounds delivery $[22,23]$. Among these approaches, nanoparticulate systems have attracted special interest because nanoparticles are able to protect active agents from degradation, improve 
biomacromolecules transmucosal transport and provide controlled-release properties for loaded bioactive compounds [24-26].

As a cationic biopolymer obtained from $\mathrm{N}$-deacetylation of chitin, chitosan had excellent features due to its non-toxicity, biodegradability, biocompatibility and bioadhesion [27-29]. Having encapsulated active compounds, chitosan was capable of protecting them from harsh conditions into gastrointestinal (GI) tract and enhances their absorption [30, 31]. In our previous researches, oleoyl-carboxymethy-chitosan (OCMCS) nanoparticles showed abilities for the sustained release of the ECPs, enhancements to mucosal delivery, and greatly improved antibody responses compared with the free ECPs in carps[32]. However, the effectiveness of OCMCS nanosystem as oral gene vaccine vehicles remained unknown.

Herein, we demonstrated nano-polyplexes (NPs) consisting OCMCS/hyaluronic acid (HA) as novel gene vaccines carriers for oral immunization in carps (Scheme 1). HA was incorporated in NPs as a target ligand attribute to its ability to bind various cellular receptors such as CD44, which was expressed in normal human epithelium cells, chondrocytes and cancerous cells $[33,34]$. Aerolysin gene (aerA) of A. hydrophila was chosen as encapsuling antigen to form OHA NPs. The DNA loading efficiency and release profile from OHA NPs was evaluated in vitro. The increased intracellular accumulation of NPs in Caco-2 cells was observed by confocal laser microscopy. The intestinal penetration enhancement properties of NPs were investigated through Caco-2 cell model and ex vivo carp intestine model. Subsequently, the serum antibody titer in carps orally immunized by OHA NPs was also investigated. We expect the OCMCS/HA NPs interesting candidates to improve immunity-boosting properties of gene vaccine after 
oral administration in water body.

\section{Materials and methods}

\subsection{Materials}

Chitosan $(\mathrm{Mw}=50 \mathrm{kDa}$, degree of deacetylation $=93.15 \%)$ was made from crab shell and obtained from Laizhou Haili Biological Product Co., Ltd. (Shandong China). Hyaluronic acid, with a molecular weight of $5 \mathrm{kDa}$, was purchased from C.P. Freda Pharmaceutical Co. Ltd. (Shangdong, China). Caco-2 cells were obtained from the American Type Culture Collection (Rockville, MD, USA) and cultured in Dulbecco's Modified Eagle Medium (DMEM) (Gibco, Grand Island, NY, USA) containing $10 \%$ fetal calf serum. Cell counting kit assay (CCK-8) was obtained from Beyotime Institute of Biotechnology (Shanghai, China). Cy3 and YOYO-1 were obtained from Invitrogen (USA).

pcDNA3.1-aerA was amplified and isolated using a Plasmid Mega Kit (QIAGEN, Valencia, CA, USA). The recovered plasmids were stored at $4{ }^{\circ} \mathrm{C}$ in sterile deionized (DI) water. The purity of plasmids was analyzed by gel electrophoresis ( $0.8 \%$ agarose), while their concentration was measured by UV absorption at $260 \mathrm{~nm}$ (V-530, Jasco, Tokyo, Japan).

Common carps weighing $200 \pm 10 \mathrm{~g}$ were used for the experiments. The animal

protocol was approved by Shandong Medical Laboratorial Animal Administration Committee. The animal experiment was carried out in accordance with the National Institutes of Health Guide for the Care and Use of Laboratory Animals (NIH Publication No. 80-23) revised in 1996.

2.2 Preparation of the nano-polyplex (NPS): OCMCS laerA (OA) NPS and 
OCMCS-HA/aerA (OHA) NPS

Oleoyl-carboxymethy-chitosan (OCMCS) was synthesized by reaction of chitosan with chloroacetic acid and oleoyl chloride as described in our previous study [35, 36]. Solutions of OCMCS at different concentrations were prepared in phosphate buffer saline (PBS, pH 6.0) in order to achieve N/P ratios of $0.5,1,2,5,10$ and 20 (an amino group to a phosphate group ratio hereafter was defined as charge or N/P ratio). A plasmid DNA solution of $50 \mu \mathrm{g} / \mathrm{ml}$ in $25 \mathrm{mM}$ of sodium sulfate was prepared. An equal volume of chitosan solution (from each concentration) and DNA solution were added (by dropping slowly) together while stirred at various speed $(100-2000 \mathrm{rpm})$. The final volume of the mixture in each preparation was limited to below $500 \mu \mathrm{l}$ in order to yield uniform OA NPs.

OHA NPs were prepared according to the method described by Duceppe and Tabrizian [37]. In brief, $5 \mathrm{mg} \mathrm{HA}$ was dissolved in $2 \mathrm{ml}$ of distilled water under magnetic stirring. The OCMCS solution was stirred at a rate of $5000 \mathrm{rpm}$ for $10 \mathrm{~min}$, mixed into the HA solution and stirred for $10 \mathrm{~min}$. Seven different mixtures were prepared with CS:HA weight ratios at $1: 1,2: 1,3: 1,4: 1,5: 1,6: 1$, and $7: 1$. The required volume of $50 \mu \mathrm{g} / \mathrm{ml}$ plasmid DNA was gently added to OCMCS/HA solution to form OHA NPs of a selected N/P ratio. The mixture was vortexed rapidly for $3-5 \mathrm{~s}$ and left for $1 \mathrm{~h}$ at room temperature for the OHA NPs to completely form.

\subsection{Size and zeta potential measurement}

The Z-average hydrodynamic diameter and surface charge of NPs were determined by dynamic light scattering (DLS) using Zetasizer Nano ZS (Malvern Instruments Ltd., UK) at room temperature. The NPs were prepared and analyzed in $1 \mathrm{ml}$ distilled water at 
$25{ }^{\circ} \mathrm{C}$. All samples were measured in triplicate. The morphological characterizations of the NPs were viewed using scanning electron microscopy (SEM, JSM-330A, Japan) and transmission electron microscopy (TEM, JEM-2010, Japan).

\subsection{Gel retarding analysis}

OHA NPs were evaluated by agarose gel electrophoresis. The NPs and the naked plasmid were loaded onto a 1\% agarose gel containing ethidium bromide in Tris-borate EDTA buffer at $\mathrm{pH}$ 8.0. The samples were run on the gel at $120 \mathrm{~V}$ for $30 \mathrm{~min}$. The gel was then photographed using a GDS-8000 (UVP, USA).

OHA NPs (N/P ratio 5) prepared with OCMCS: HA weight ratios of 4:1 and naked DNA solution (each containing $1 \mu \mathrm{g}$ of DNA) were added to $10 \mathrm{U}$ of $\mathrm{BamHI}$ and $15 \mathrm{U}$ HindIII (Sigma-Aldrich, USA) and kept in a water bath for 30 min at $37^{\circ} \mathrm{C}$. In addition, different concentrations (56-336 ng/ $\mu \mathrm{l}$ ) of chitosanase (from streptomyces species, activity 18 units/mg, Sigma-Aldrich, USA) were added and the NP-chitosanase solution was maintained in a water bath for $4 \mathrm{~h}$ at $37{ }^{\circ} \mathrm{C}$ Agarose gel (1\%) electrophoresis was repeated, as described above.

\subsection{DNA loading and releasing}

The OA NPs and OHA NPs (N/P ratio 5 and OCMCS/HA weight ratio 4) were formed according to the method described in Section 2.2. After complex was completely formed at ambient temperature for $30 \mathrm{~min}$, the turbid solution was centrifuged at $20,000 \times \mathrm{g}$ at $4{ }^{\circ} \mathrm{C}$ for $30 \mathrm{~min}$ and the supernatant was collected to determine the amount of free DNA. The loading efficiency (LE \%) of DNA was calculated by Eq. (1), and the analyses were performed in triplicates.

$\mathrm{LE} \%$ of $\mathrm{DNA}=\left[\frac{A-B}{A}\right] \times 100$ 
Where $A$ was the total concentration of DNA $(\mathrm{mg} / \mathrm{ml})$ and $B$ was the concentration of unloaded DNA $(\mu \mathrm{g} / \mathrm{ml})$.

The digestive tract of carps was undeveloped and could be divided into buccopharyngeal cavity, esophagus, stomach and intestine (foregut, midgut, and hindgut) $[38,39]$. The stomach of carp was immature with weak acidic $\mathrm{pH}$ condition around $\mathrm{pH}$ 6.0, while the intestine segments were suitable for oral vaccines due to its neutral environment and decreased enzymatic activity [40]. The nano-polyplex were introduced into two different kinds of simulated fluid and kept in a water bath at $25{ }^{\circ} \mathrm{C}$. Acetate buffer ( $\mathrm{pH}$ 6.0, 0-20 h) and PBS buffer ( $\mathrm{pH} \mathrm{7.4,} \mathrm{20-50} \mathrm{h)} \mathrm{were} \mathrm{used} \mathrm{as} \mathrm{media} \mathrm{for} \mathrm{the}$ DNA release study, respectively. Dried OA NPs and OHA NPs (3.9 mg) and SDF (1.2 ml) were placed in a micro tube and incubated in a water bath at $25 \pm 0.5^{\circ} \mathrm{C}$, respectively. At the sampling time, the incubated dispersing solution was centrifuged, and $400 \mu \mathrm{l}$ of supernatant was collected for evaluation of the amount of released DNA using a spectrophotometer at $258 \mathrm{~nm}$. An equal volume of fresh buffer was, then, replaced in the solution and the same procedure was repeated for the next sampling time. The accumulative release percentage (Q \%) was calculated by Eq. (2), and the analyses were performed in triplicates.

$\mathrm{Q} \%=\frac{C_{n} V+V_{i} \sum_{i=0}^{n-1}}{D N A_{t} \times L E \%} \times 100$

where $C_{n}$ was the DNA concentration at $T_{n}, \mathrm{~V}$ was the total volume of release medium, $V_{i}$ was the sampling volume at $T_{i}, C_{i}$ was the DNA concentration at $T_{i}$ (both $V_{0}$ and $C_{0}$ were equal to zero), $D N A_{t}$ was the total amount of DNA used for preparation of the original mixture, $L E \%$ was the loading efficiency of DNA loaded into the nanoparticulate 
systems.

2.6 Cytotoxicity assay

\subsubsection{Cell culture}

Caco-2 cells were cultured in regular growth medium consisting of Dulbecco's Modified Eagle medium (DMEM) supplemented with $10 \%$ fetal bovine serum (FBS), $100 \mathrm{U} \mathrm{mL}^{-1}$ penicillin, and $100 \mu \mathrm{g} \mathrm{mL}^{-1}$ streptomycin, and kept in an atmosphere of 5\% $\mathrm{CO}_{2}$ and $95 \%$ air at $37^{\circ} \mathrm{C}$.

\subsubsection{Evaluation of cytotoxicity}

Caco- 2 cells were seeded in 96 -well plates at $5 \times 10^{4}$ cells $/ \mathrm{ml}$ in $100 \mu$ l of complete DMEM medium, and incubated at $37^{\circ} \mathrm{C}$ in $5 \% \mathrm{CO}_{2}$ humidified atmosphere for $24 \mathrm{~h}$. The culture medium was then replaced with $100 \mu$ of freshly prepared culture medium containing OA or OHA NPs. After $24 \mathrm{~h}$ incubation, the cell viability was investigated by the CCK-8 assay. Meanwhile, the cytotoxicity of the NPs $(200 \mu \mathrm{g} / \mathrm{ml})$ at different $\mathrm{pH}$ values (6.0 and 7.4) was also tested after $24 \mathrm{~h}$ of incubation time with Caco-2 cells.

\subsection{In vitro cellular uptake of nano-polyplex}

Caco-2 cells in DMEM medium were seeded on glass-bottomed dishes $(35 \mathrm{~mm}$, kindly provided by MatTek Corporation) for $24 \mathrm{~h}$ to form a confluent monolayer. Then the culture medium was replaced by serum-free medium and preincubated at $37{ }^{\circ} \mathrm{C}$ for 30 min. After equilibration, the culture medium was changed with $1 \mathrm{ml}$ of freshly prepared Cy3-labeled OHA NPs suspension $(100 \mu \mathrm{g} / \mathrm{ml})$ and incubated at $37{ }^{\circ} \mathrm{C}$ for $2 \mathrm{~h}$. To investigate influence of HA on cellular internalization of NPs, free HA as a CD44 receptor blocking agent at concentrations 10 times greater than the HA content of OHA

NPs was added to the cells and incubated for $20 \mathrm{~min}$ at $37{ }^{\circ} \mathrm{C}$. The experiment was 
terminated by washing the cell monolayer three times with PBS and stained with 10 $\mu \mathrm{g} / \mathrm{ml}$ Hochest 33342 for $10 \mathrm{~min}$. The glass-bottomed dishes were viewed by confocal laser scanning microscope (LSM 710 METS, Carl Zeiss Inc.). Cy3-labeled OA NPs performed as a control group. We used MetaXpress and Image $\mathbf{J}$ software to quantitatively express intracellular Cy3 fluorescence in the different treatment groups.

\subsection{Enhanced permeation measurements in vitro}

\subsubsection{Excised intestinal tissues permeation measurements}

The nano-polyplexes, suspended in Hank's Balanced Salt Solution (HBSS) buffered at $\mathrm{pH}$ 6.5, were subjected to permeation measurement by means of Franz diffusion cells with a $2 \mathrm{~cm}^{2}$ orifice area thermostated at $25^{\circ} \mathrm{C}$. The segments of carp intestine laying on a filter paper, was placed between the donor and the acceptor chambers of the Franz diffusion cell. The receptor chamber of the cell was filled with $25{ }^{\circ} \mathrm{C}$ phosphate buffer ( $\mathrm{pH}$ 6.8). YOYO-1 was used to label the plasmid DNA. $500 \mu \mathrm{l}$ of YOYO-1-labeled OHA or OA NPs in phosphate buffer $(\mathrm{pH}$ 6.0) at a concentration of $2 \mathrm{mg} / \mathrm{ml}$ were placed on the excised carp intestine at $25^{\circ} \mathrm{C}$ and protected from light for $3 \mathrm{~h}$. At fixed time intervals, $500 \mu \mathrm{l}$ samples of the acceptor phase were withdrawn and replaced with fresh buffer. YOYO-1 labeled DNA was assayed by means of spectrofluorimetric detection. As control, the permeation test of YOYO-1 labeled free DNA solution in phosphate buffer $(\mathrm{pH}$ 6.0), at the same concentration of nanoparticulate systems was performed. The apparent permeability coefficient $\left(P_{\text {app }}\right)$ was calculated using the following Eq. (3):

$$
P_{\mathrm{app}}=\frac{d Q}{d t} \cdot \frac{1}{A} \cdot C_{0} \cdot 60
$$

Where $P_{\text {app }}$ was the apparent permeability $(\mathrm{cm} / \mathrm{s}), d Q / d t$ was the permeability rate, $A$ was the diffusion area of the membrane $\left(\mathrm{cm}^{2}\right)$, and $C_{0}$ was the initial concentration of the 
DNA.

\subsubsection{Caco-2 cell monolayer permeability studies}

Caco-2 cells, with a passage number 25 - 30, were cultured on polycarbonate membrane filters (pore size $0.3 \mu \mathrm{m}$, area $0.33 \mathrm{~cm}^{2}$ ) in Corning Transwell 24-well plates (Corning Incorporated, Europe) at a seeding density of $3 \times 10^{4}$ cells $/ \mathrm{ml}$. The culture medium was added to both the apical and the basolateral compartments and was changed every second day for 21 days. Afterwards, the cells were post-fixed with $1 \%$ osmium tetroxide in $0.1 \mathrm{M} \mathrm{NaCac}$ buffer ( $\mathrm{pH}$ 7.4). The cells were then dehydrated and embedded in epoxy resin. Ultrathin sections $(60 \mathrm{~nm})$ were cut parallel to the coverslip, post-stained with uranyl acetate and lead citrate, and examined with a TEM FEI Tecnai 10 (Philips) at $120 \mathrm{kV}$.

The transepithelial electrical resistance (TEER) across cell monolayers was monitored by means of a volt ohmmeter with a pair of chopstick electrodes (Millipore Corp. Bedford, MA, USA) during cell culture to investigate the integrity of the prepared monolayer (Sadeghi et al., 2008). Only monolayers with TEER values higher than $450 \Omega$ $\mathrm{cm}^{2}$ were used in the permeation study. For the transport research, YOYO-1 labeled DNA was used in free form and in the form of NPs suspensions. Consequently, $2.0 \mathrm{ml}$ of $0.25 \mathrm{mg} / \mathrm{ml}$ final concentration of free DNA and $0.25 \mathrm{mg} / \mathrm{ml} \mathrm{NPs}$ were added to the apical side of the cell culture dish. The transport experiments were performed in HBSS at $\mathrm{pH} 6.5$ (apical compartment) at $37^{\circ} \mathrm{C}$ using an orbital shaker $(50 \mathrm{rpm})$. The solution in the basolateral compartment was kept at $\mathrm{pH} 7.4$ in all the experiments. Samples of $200 \mu \mathrm{l}$ were withdrawn from the basolateral part at predetermined time of $15,30,45,60,120$ and $240 \mathrm{~min}$ and replaced with equal volumes of fresh HBSS. The samples were 
analyzed for the YOYO-1 labeled DNA content using a fluorescence microplate reader (Polarstar, Germany). The $P_{\text {app }}$ was calculated according to the Eq. (3). After $2 \mathrm{~h}$, the samples were carefully removed from the apical part and the cell monolayers were rinsed and replaced with fresh culture medium for evaluation of TEER recovery. The monolayers were allowed to incubate for $24 \mathrm{~h}$ at $37^{\circ} \mathrm{C}$ in regular cell culture conditions. The TEER was monitored at predetermined time intervals of $0,0.5,1,2,4,8$ and $24 \mathrm{~h}$. The experiments were done in triplicate.

\subsection{In vivo transfection assay}

\subsubsection{Transfection study of nano-polyplex in vivo}

In vivo nano-polyplex transfection was evaluated by measuring the serum antibody titres after oral administration in carps. Carps $(n=4)$ were immunized orally with OHA NPs (N/P ratio of 5 and OCMCS: HA weight ratio of 4:1), $500 \mu \mathrm{l}$ of OA NPs (N/P ratio of 5) or free pCDNA3.1-aerA DNA concentration $5 \mu \mathrm{g} / \mathrm{carp}$ by using a feed syringe. Immunization was repeated three times at 2-week intervals. Sera were collected 2 weeks after the primary, secondary and last immunization, respectively, for antibody assay. Furthermore, an additional set of carp $(n=4)$ were acted as non immunized control. Sera from non-immunized control carp was also used for antibody assay.

\subsubsection{Collection of antigen and ELISA study}

Aerolysin of $A$. hydrophila were chosen as antigen and purified on the basis of the method of Rodriguez et al[41]. Protein content of aerolysin was assayed spectrometrically at $595 \mathrm{~nm}$ using the Bradford protein assay. Specific antibodies against A. hydrophila were determined by enzyme-linked immunosorbent assay (ELISA)[42]. Antibody titres were expressed as the $\log _{2}$ of reciprocal of endpoint dilution exhibiting 
A450 more than three times that of background.

\subsubsection{Histopathology assays}

The toxicity of the nano-polyplex was evaluated in vivo. Carp $(n=4)$ were reared in $10 \mathrm{~L}$ plastic aquaria that were filled with dechlorinated tap water (water temperature $25^{\circ} \mathrm{C}$ ) and aerated. Animals were randomly divided into four groups: the experimental groups were fed orally with OHA NPs, OA NPs and free DNA solution (DNA concentration $10 \mu \mathrm{g}$ per carp) by using a catheter for 7 days; Carps orally treated with PBS acted as a control group. Animals were observed carefully for the onset of any signs of toxicity. After sacrificed, internal organs of each animal were harvested and observed grossly. For histological examinations, the kidney, liver, spleen, and intestine were collected from each animal. Tissues were fixed with formalin, and tissue sections cut and processed using routine histological methods in an automated system. Sections of $5 \mu \mathrm{m}$ were prepared after paraffin embedding. The slides obtained were stained with routine hematoxylin and eosin staining method in an automated stainer.

\subsection{Statistical analysis}

All experiments were repeated at least three times. All data were presented as mean \pm standard deviation ( \pm SD). A two-way analysis of variance (ANOVA) for multiple comparisons, followed by post-hoc test was used to analysis the data. A $P$ value of less than 0.05 was considered statistically significant. Calculations were done using the software Origin 8.0.

\section{Results and discussion}

\subsection{Physicochemical characterization of nano-polyplex}

The nano-polyplex was formed as a result of complex coacervation. The size of 
nano-polyplex was important for cellular uptake and could be affected by the N/P ratio and OCMCS: HA weight ratio as demonstrated in Fig. 1. The effect of charge ratio on the particle size and surface charge was examined at N/P ratios of 0.5-20. As shown in Fig. 1A, OHA NPs with N/P ratios of 5 had the smallest sizes $(154.5 \pm 9.4 \mathrm{~nm})$. The zeta potential of OHA NPs increased slightly with the N/P ratio (ranging from -2.4 to +15.8 $\mathrm{mV}$ ). At N/P ratio below 1, OCMCS was unable to condense DNA which resulted in negative zeta potential. The increase of surface charge with N/P ratio over 1 could be result from the exclusion of redundant positive charge provided by OCMCS inside NPs.

The influence of the OCMCS/HA ratio (w/w) on the size of NPs was shown in Fig. 1B. The size and zeta potential of the NPs were dependent on the composition, with an increase in size and a decrease in the surface charge with increasing HA content. The NPs showed the smallest particle size $(167.9 \pm 11.3 \mathrm{~nm})$ with OCMCS/HA weight ratio of 4 . At OCMCS/HA weight ratio below 4, significant decreases turned up in particle sizes with increasing ratios, however, it only varied slightly with N/P ratio over 4 . The zeta potential becomes more positive as the amount of OCMCS within the polyelectrolyte complex increases (from +7.1 to $+16.3 \mathrm{mV}$ ).

The surface charge should be considered when the complex was introduced into the body. Although positively charged NPs could be attached to the cell membrane and enter the cell more easily, NPs with high positive charge should be avoided because it might cause toxic side effects on cells, nonspecific interactions between complex and cells, and also exchange reactions of DNA with negatively charged macromolecules existing in the body during delivery. The experimental conditions were maintained for further analyses, because the OHA NPs with N/P ratio 5 and OCMCS/HA ratio (w/w) 4 presented the 
desired features in terms of size and zeta potential.

The morphological characterizations of the OHA NPs $(\mathrm{N} / \mathrm{P}=5, \mathrm{OCMCS} / \mathrm{HA}=4)$ were evaluated by SEM (Fig. 2A) and TEM (Fig. 2B). The NPs had similar nanometric dimension and showed round shaped particles with a size around $150 \mathrm{~nm}$, which was in accordance with the diameter obtained by DLS.

\subsection{Integrity of the associated DNA}

Integrity of the associated plasmid DNA and protection against nuclease degradation by nanoparticles were determined by agarose gel electrophoresis. Gel electrophoresis indicated when the N/P ratio was above 1 , the DNA was totally retained within the gel loading well, which illustrated the complete coalesce of plasmid with OCMCS (Fig. 2C).

As revealed in Fig. 2D, NPs with OCMCS-HA protected DNA from degradation by BamHI and HindIII (lane 5) while naked DNA was completely degraded (lanes 2 and 3). The integrity of the associated DNA was confirmed after degradation of the NPs with chitosanase (lane 4). The NPs with OCMCS-HA (lane 7) protected the DNA against degradation when chitosanase was added following BamHI and HindIII. On the contrary, DNA was completely degraded (lane 6) when chitosanase was added previously. The results indicated that OCMCS-HA was capable to load DNA efficiently and preserve its integrity.

\subsection{DNA loading and release in vitro}

The LE of DNA into the complex was calculated based on the total amount of DNA added in the NPs preparation step. The HA introduced into the NPs did not interfere with DNA loading, and the LE of DNA in OA NPs and OHA NPs was $96.23 \pm 5.22 \%$ and $92.31 \pm 3.21 \%$, respectively (Table 1$)$ 
The releasing profiles of DNA from the OA NPs and OHA NPs were investigated in different $\mathrm{pH}$ environment at $25 \pm 0.5^{\circ} \mathrm{C}$. The amount of released DNA was measured by a spectrophotometer at $258 \mathrm{~nm}$. Two kinds of NPs showed similar release tendency in acetate buffer $(\mathrm{pH}$ 6.0). There was an initial burst in the first $2 \mathrm{~h}$ and then a sustaining release up to around 10\% of the total DNA from OA NPs and OHA NPs after incubation for $20 \mathrm{~h}$ at $\mathrm{pH} 6.0$ (Fig. 3A). Afterwards, the release medium was replaced to PBS (pH 7.4). It should be pointed out that OA NPs and OHA NPs exhibited quite different releasing profiles within $20 \mathrm{~h}-50 \mathrm{~h}$ of incubation in SIF. The cumulative release of DNA from OA NPs was about $31 \%$ in SIF due to partial amino deprotonation causing the weaker electrostatic interaction between OCMCS and DNA. However, much more release of DNA was observed when OHA NPs were incubated at $\mathrm{pH} 7.4$, and over 77\% of cumulative release was detected under the identical conditions. Because of the existence of negative charged HA, the electrostatic interaction between these oppositely charged macromolecules-OCMCS and DNA was seriously weakened, resulting in the fairly fast release of DNA.

The corresponding TEM images of were taken to visualize the morphology of OHA NPs simulating the environment in the GI tract. As shown in Fig. 3B, no significant differences were detected in the sizes of OHA NPs pH 6.0 in SDF. At pH 7.4 in SIF, the structure of OHA NPs had gotten loosened and disintegrated. These results were consistent with in intro DNA release data.

\subsection{Cytotoxicity analysis}

In order to develop OHA NPs as novel gene delivery carriers for GI system, an assessment of any potential toxic interaction with intestinal epithelia is significant. The 
cytotoxicity of OA NPs and OHA NPs to Caco-2 cells was estimated using the CCK-8 assay. As depicted in Fig. 3C, compared with untreated cells, the Caco-2 cells retained more than $90 \%$ viability when treated with various concentrations $(100-1000 \mu \mathrm{g} / \mathrm{ml})$ of OA NPs or OHA NPs. Meanwhile, blank NPs $(1000 \mu \mathrm{g} / \mathrm{ml})$ exhibited no obviously cytotoxicity for Caco-2 cells at different $\mathrm{pH}$ values (6.0 and 7.4) (Fig.3D).

\subsection{Cellular uptake assay}

To estimate the cellular uptake efficiency of OHA NPs and OA NPs, Caco-2 cells were subjected to confocal laser scanning microscope (CLSM). The fluorescent intensity in Caco-2 cells treated with Cy3 labeled OHA NPs was 2.5 -fold higher $(\mathrm{P}<0.05)$ than that of Cy3 labeled OA NPs at $4 \mathrm{~h}$ observation period (Fig. 4A and 4B). HA was known for its implication in several processes, such as the regeneration of corneal and conjunctival epithelial cells, through an interaction with the CD44 receptor[43]. With the objective of elucidating whether CD44 has been responsible for the receptor-mediated uptake[44], we blocked the receptor by the addition of excess free HA. As expected, the cellular uptake of OA NPs varied negligibly after the receptor blockage. On the contrary, the excess free HA caused a significant decrease $(\mathrm{p}<0.01)$ of mean fluorescence intensity when the cells were treated with OHA NPs. Consequently, we concluded that the targeting ligand HA incorporated in OHA NPs was capable to enhance cellular internalization.

\subsection{In vitro permeability studies}

\subsubsection{TEER measurements}

The transepithelial electrical resistance (TEER) across Caco-2 monolayers was measured to evaluate the integrity of the Caco- 2 cell monolayers used in the permeation 
experiments 21 - 28 days after the seeding. The initial TEER values were in the range of $734.7 \pm 52.3 \Omega \mathrm{cm}^{2}$ with no monolayer less than $450 \Omega \mathrm{cm}^{2}$, indicating integrity of the prepared monolayers, which was able to mimic the intestinal epithelium (Fig. 5A). In order to further explore the integrity of the Caco-2 cell monolayers, the ultrathin sections were detected by TEM. The microvilli (a) and the tight junction (b) were visible in Fig. 5B and Fig. 5C.

The variations in TEER of Caco- 2 cell monolayers were measured to evaluate the effect of the different formulations on the paracellular permeation of DNA (Fig.5D). Compared with the group treated with free DNA, a remarkable TEER decrease was observed within the first $30 \mathrm{~min}$, after the apical addition of the OHA NPs or OA NPs suspensions were added to the monolayers. The lowering of the TEER $\%$ profiles implicated that the nanoparticulate systems were responsible for the modulation of the cell junction integrity. The possible mechanisms for the NPs facilitating opening of tight junctions seemed to be based on the positive charges of the OCMCS, which interact with the cell membrane resulting in a structural reorganization of tight junction-associated proteins. To evaluate TEER-reversibility, the monolayers were rinsed and allowed to regenerate in fresh medium after $2 \mathrm{~h}$ incubation period with the different samples. The cell monolayers displayed a transient and reversible decrease in TEER. Approximately complete recovery of the observed effects was achieved within $24 \mathrm{~h}$, indicating that changes in TEER were not mediated through the damage of tight junctions or permanent changes of membrane function.

\subsubsection{Permeation enhancement in vitro}

The permeation of YOYO-1 labeled DNA across excised carp intestine and Caco-2 
cell monolayers was evaluated by fluorescence microplate reader, respectively. Compared to free DNA, both OHA NPs and OA NPs increased the permeation of DNA as revealed in Fig. 6A. It was found that the apparent permeability coefficient $\left(P_{\text {app }}\right)$ varied negligibly with incorporation of HA in NPs. The $P_{\text {app }}$ values of DNA across excised carp intestine in OHA NPs and OA NPs were 5.45 and 5.87 folds higher than that in the free DNA solution, which were $5.89 \pm 0.27 \times 10^{-7} \mathrm{~cm} / \mathrm{s}$ and $6.35 \pm 0.43 \times$ $10^{-7} \mathrm{~cm} / \mathrm{s}$, respectively. For Caco- 2 cell monolayers, the $P_{\text {app }}$ values of DNA loaded in OHA NPs and OA NPs were $6.82 \pm 0.41 \mathrm{~cm} / \mathrm{s} \times 10^{-7}$ and $7.12 \pm 0.39 \mathrm{~cm} / \mathrm{s} \times 10^{-7}$, respectively, which was significantly higher by 5.82 folds and 6.08 folds as compared to that of free DNA. These findings supported the TEER measurement results and indicated that NPs had proved as an effective penetration enhancer of hydrophilic and/or high molecular weight molecules across the intestinal epithelium even in neutral environments by means of the mechanism (tight junctions opening and widening of paracellular pathway).

\subsection{ELISA study}

ELISA studies were carried out to examine the effect of oral immunization of carps. Serum antibody titres in carps orally fed with OHA NPs, OA NPs, free DNA or PBS were measured 2 weeks after primary, secondary and third immunization (Fig. 6B). Antibody titers increased significantly 14 days after secondary immunization (28 days after primary immunization) when fish were immunized with OHA NPs. 14 days after the last immunization (42 days after primary immunization), the highest antibody responses were observed. OA NPs treatment group demonstrated significant lower $(\mathrm{P}<0.01)$ antibody titres compared with that immunized with OHA NPs and slightly higher than 
free DNA. There was no detectable antibody in serum of carps treated with PBS. These data indicated OHA NPs could effectively protect the vaccine from degradation when passing through the fish GI tract and delivered DNA to transport across the intestinal epithelium to induce adaptive immune response. The introduction of HA in OHA NPs undertook intracellular pathways that favored the gene expression.

\subsection{Histopathology assays}

The systemic toxicity of the nanoparticulate delivery system was investigated by histopathology assays (Fig. 6C). No significant differences in pathological signs were detected between the mice received OHA NPs and the untreated control group. All above results meant that OHA NPs did not cause the unexpected side effects and could be used as safe drug carriers.

\section{Conclusions}

The present study demonstrated the potential of oral immunization for induction of humoral immune responses in carp. OHA NPs were successfully prepared as novel, nonviral vectors for antigen gene delivery. The optimum N/P ratio was found to be 5 with the ideal OCMCS/HA weight ratio of 4 which resulted in the smallest nanoparticles. Involving HA in OHA NPs was beneficial for the DNA release as well as cellular uptake. As shown in permeation studies on Caco-2 monolayer and freshly collected carp intestinal mucosa, the OHA NPs had a strong permeation-enhancing effect for DNA. Biocompatibility assessment revealed OHA NPs were low toxicity. Oral administration of OHA NPs induced a significant higher antibody response compared to OA NPs under the same conditions. We envision that the nano-polyplex based on oleoyl-carboxymethy-chitosan (OCMCS) and hyaluronic has the potential to be 
developed as a oral gene vaccine delivery platform for protective immunity in carps.

\section{Acknowledgements}

This work was supported by the National Natural Science Foundation of China (31500807), the National Science Foundation for Post-doctor (2014M560579), the Fundamental Research Funds for the Central Universities (201513009) and Applied Basic Research Plan of Qingdao (15-9-1-73-jch).

Table 1: Loading efficiency (LE) and in vitro release amount of DNA in OA NPs and OHA NPs (N/P ratio 5 and OCMCS/HA weight ratio 4).

\begin{tabular}{cccc}
\hline & & \multicolumn{2}{c}{ Release amount of DNA (\%) } \\
\cline { 3 - 4 } Samples & LE of DNA $(\%)$ & Acetate buffer & PBS \\
& & $(\mathrm{pH} \mathrm{6.0)}$ & $(\mathrm{pH} \mathrm{7.4)}$ \\
\hline OA NPs & $96.23 \pm 5.22$ & $8.5 \pm 1.7$ & $31.4 \pm 2.7$ \\
OHA NPs & $92.31 \pm 3.21$ & $11.4 \pm 1.9$ & $77.4 \pm 2.7$ \\
\hline
\end{tabular}



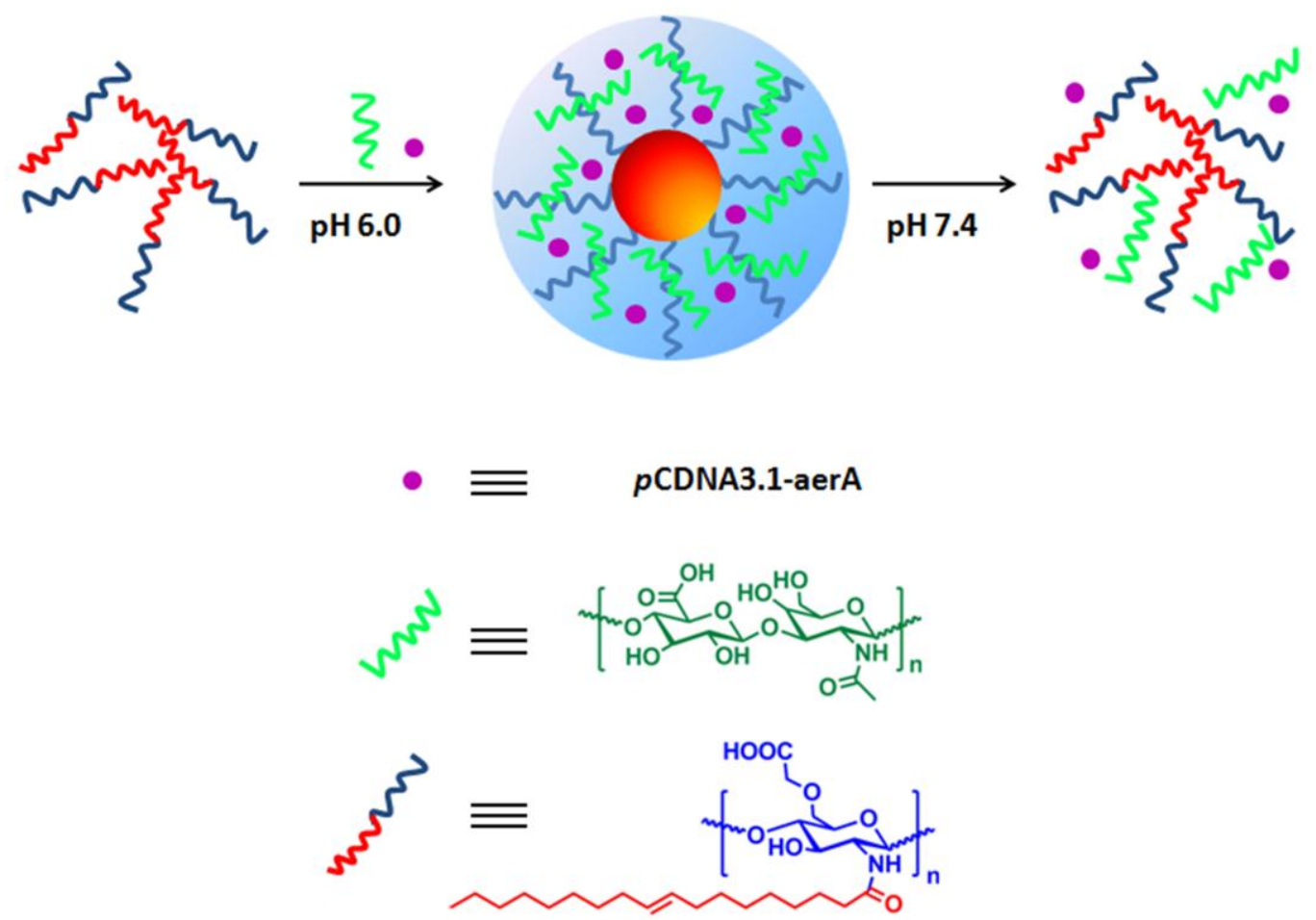

Scheme 1. Illustration of preparation of nano-polyplexes (NPs) consisting OCMCS/hyaluronic acid (HA) as novel gene vaccines carriers and in vitro release of DNA in PBS. 
A
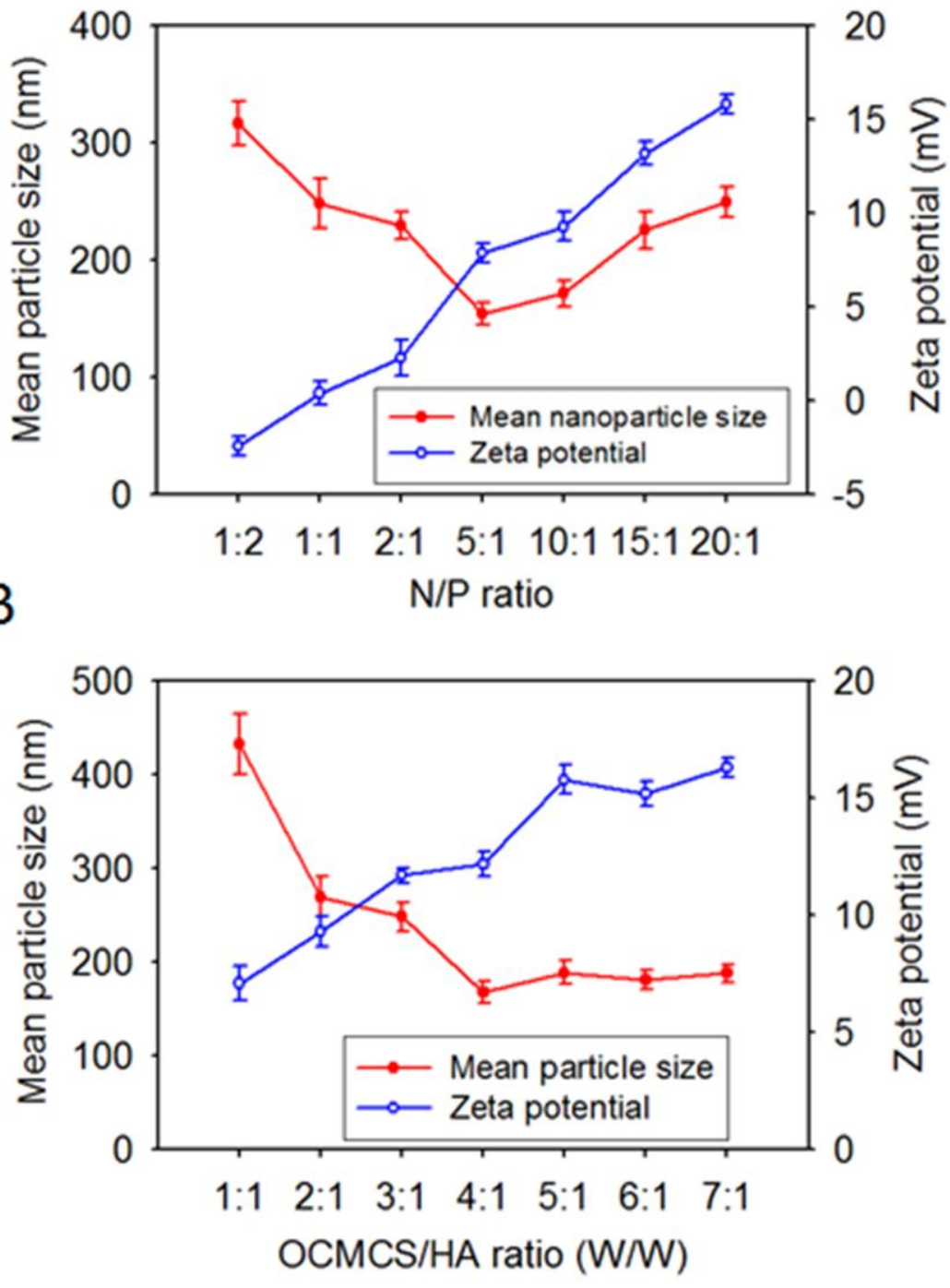

Figure 1. Effect of N/P ratio (A) and OCMCS/HA ratio (w/w) (B) on particle size and zeta potential of OHA NPs. 

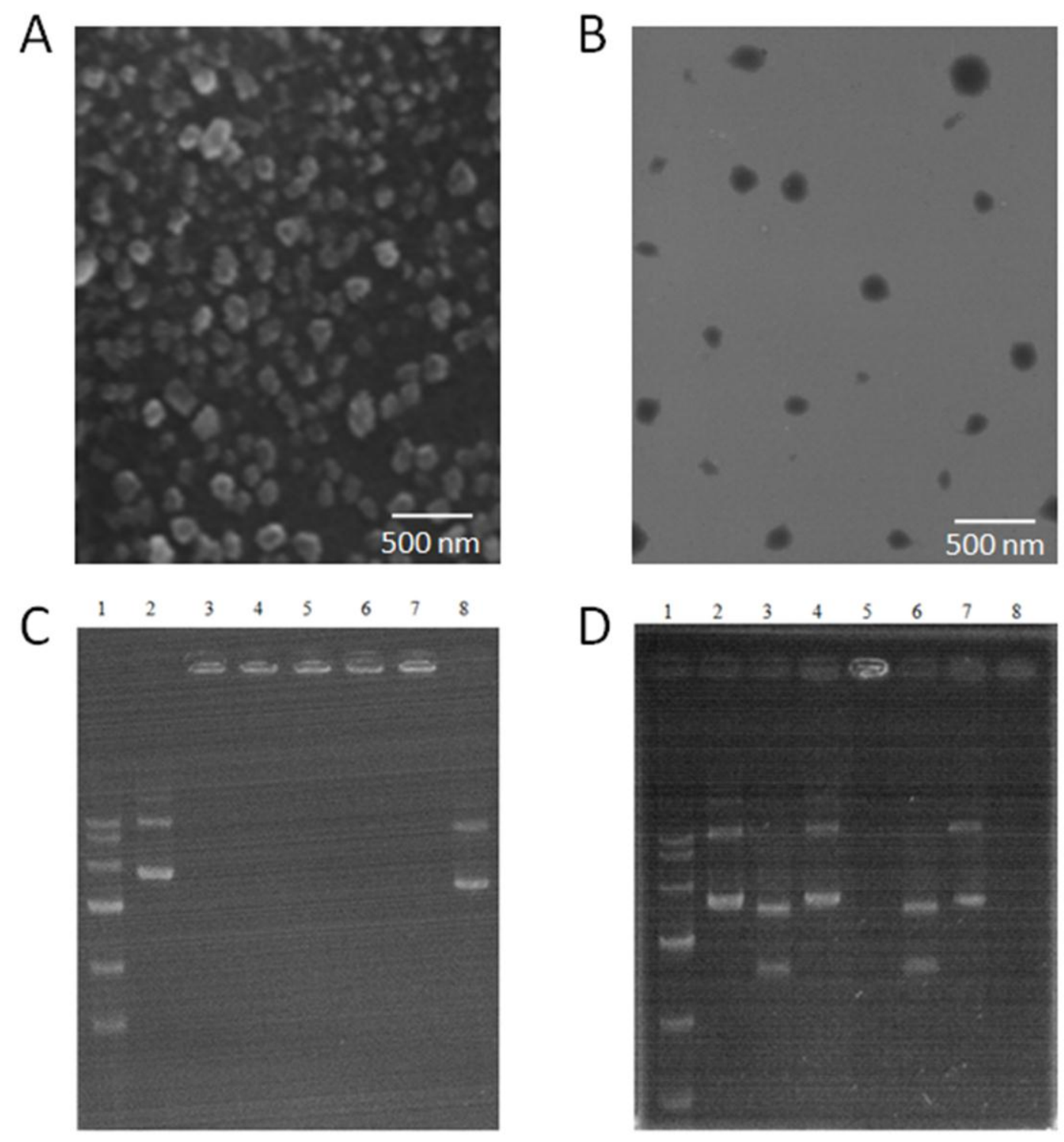

Figure 2. SEM (A) and TEM (B) imaging of OHA NPs. C) Gel retarding analysis of OHA NPs; Lane 1, DNA ladder; Lane 2, naked DNA; Lanes 3-8, OHA NPs prepared at N/P ratios of 20:1, 10:1, 5:1, 2:1, 1:1 and 1:2, respectively. D) Electrophoresis of OHA NPs to determine the integrity of plasmid; NPs were digested with chitosanase and DNase after synthesis. Lane 1, DNA ladder; Lane 2, naked DNA; Lane 3, naked DNA+ BamHI and HindIII; Lane 4, OHA NPs + chitosanase; Lane 5, OHA NPs + BamHI and HindIII; Lane 6, OHA NPs + chitosanase+ BamHI and HindIII; Lane 7, OHA NPs + BamHI and HindIII + chitosanase. 

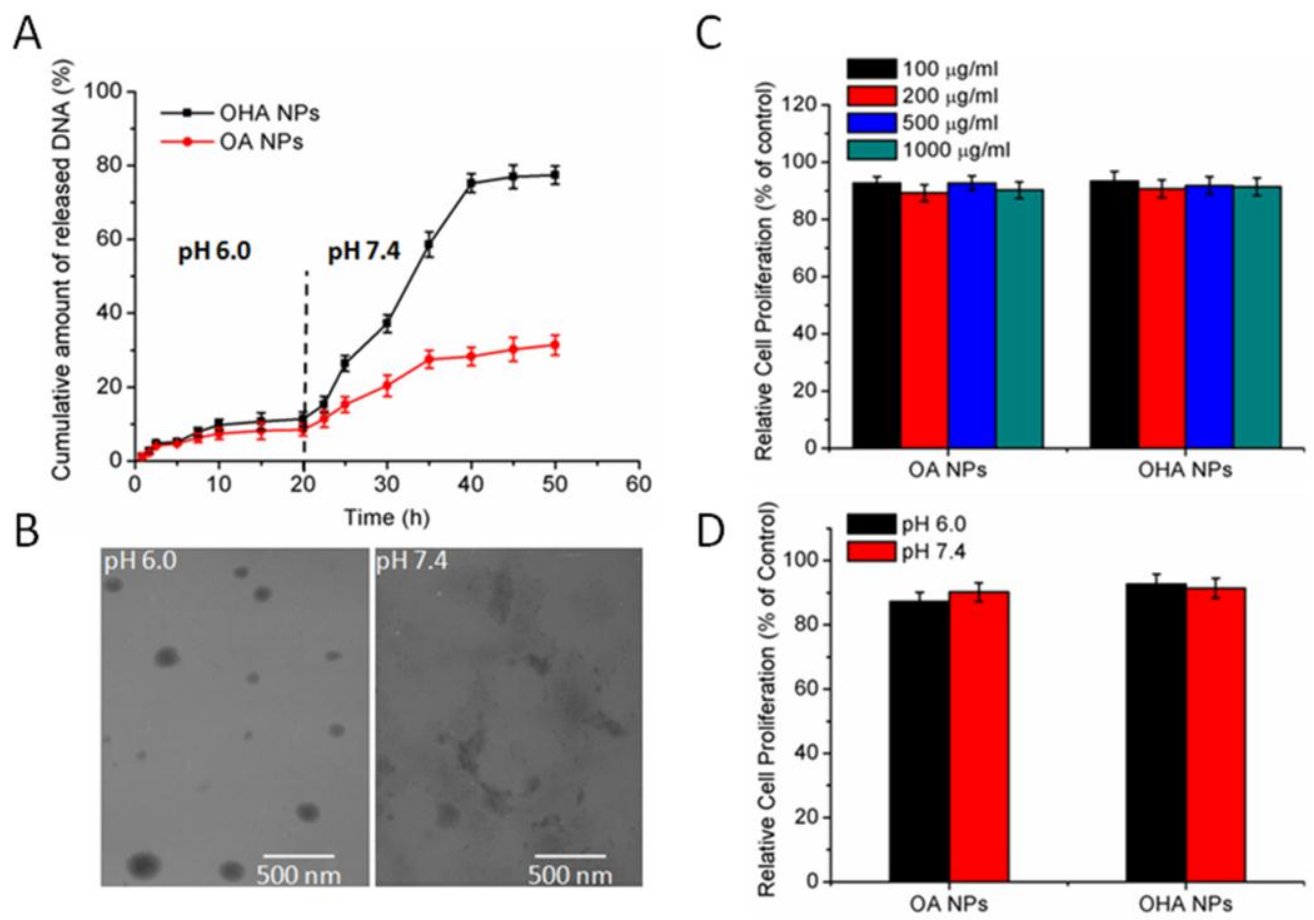

Figure 3. A). In vitro releasing profile of DNA at $25 \pm 5{ }^{\circ} \mathrm{C}$ from OHA NPs and OA NPs in acetate buffer ( $\mathrm{pH}$ 6.0) and PBS (pH 7.4), respectively. B). TEM images of OHA NPs in acetate buffer ( $\mathrm{pH}$ 6.0) and PBS ( $\mathrm{pH}$ 7.4). C) In vitro cytotoxicity of OA NPs and OHA NPs on Caco-2 cells at different concentrations from $100 \mu \mathrm{g} / \mathrm{ml}$ to $1000 \mu \mathrm{g} / \mathrm{ml}$. D) In vitro cytotoxicity of OA NPs and OHA NPs on Caco-2 cells at different $\mathrm{pH}$ environments. Data represent the mean $\pm \operatorname{SD}(n=6)$. 


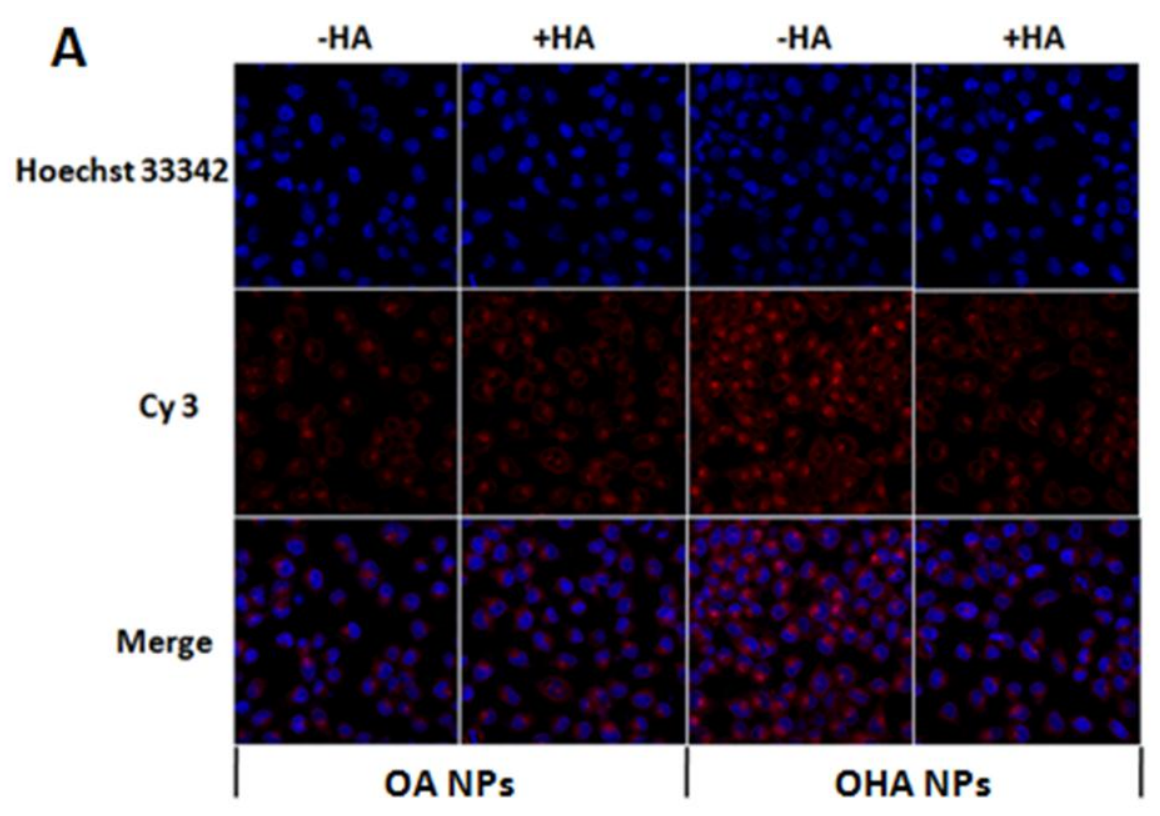

B

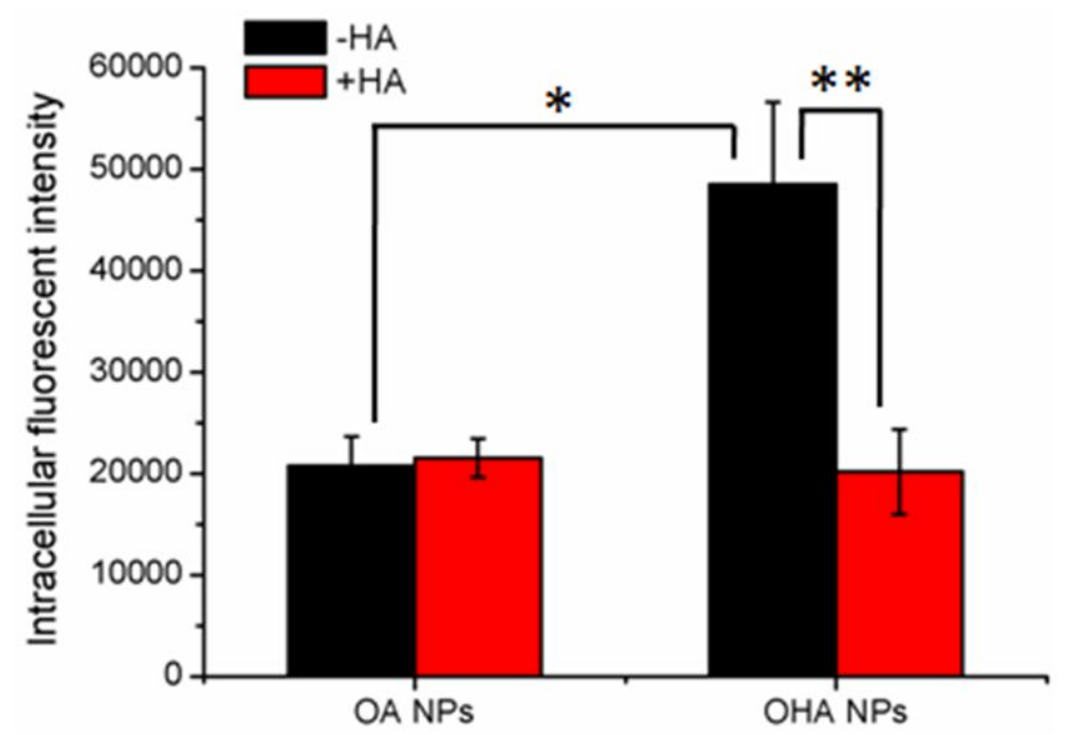

Figure 4. A) CLSM images of the internalization of Cy3 labeled OA NPs and OHA NPs in Caco-2 cells after incubation for $2 \mathrm{~h}$ in the presence and absence of free HA as an inhibitor. Cells were counter-stained with Hochest 33,342 (blue) for nuclei. B) Quantitatively express intracellular fluorescence in the different treatment groups. Asterisks (*) or double asterisks $(* *)$ denoted statistical significance; $*, \mathrm{P}<0.05 ; * *, \mathrm{P}<$ 0.01 . 

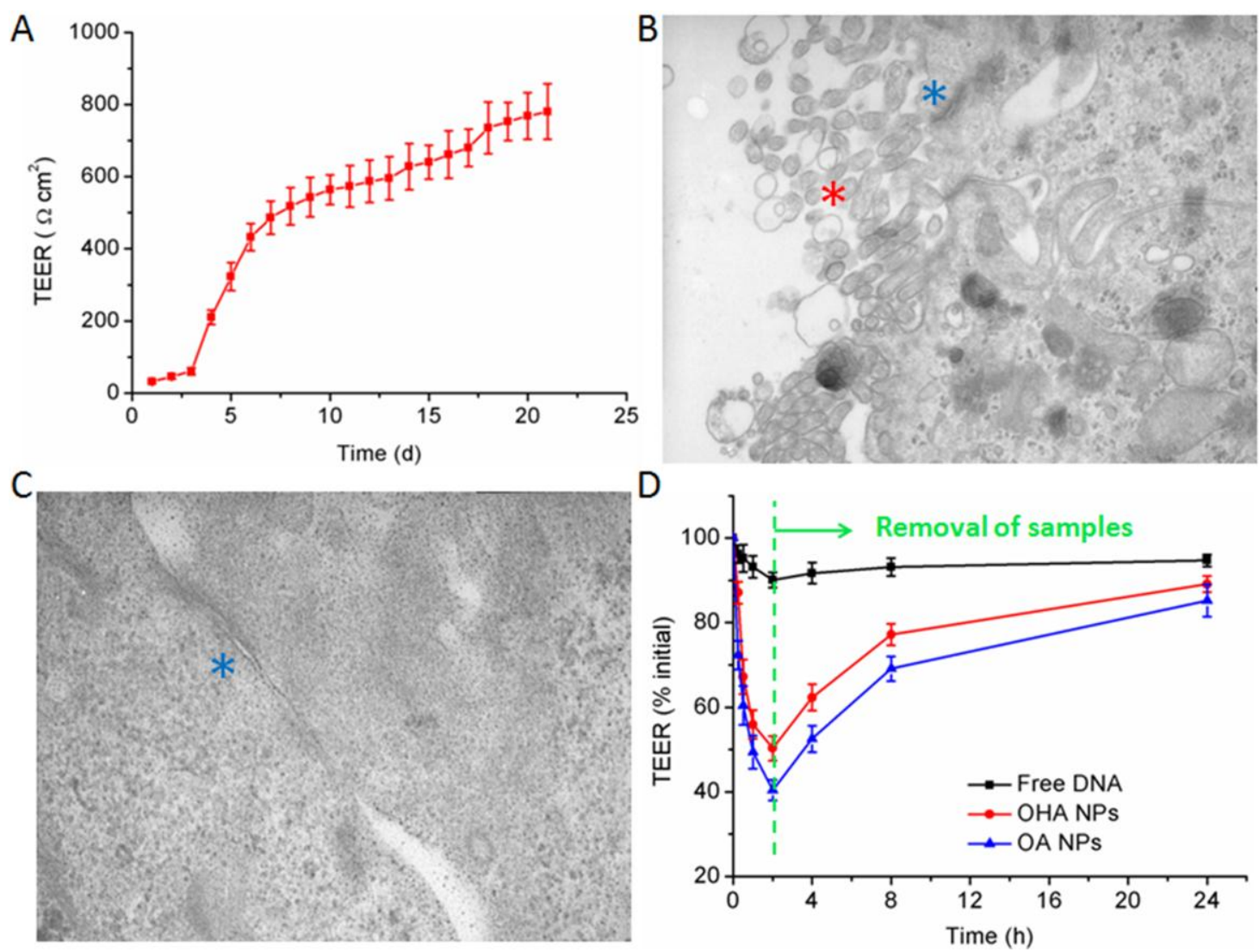

Figure 5. A) The variation of TEER of Caco- 2 cell monolayers during the culture of $21 \mathrm{~d}$. B) and C) TEM images of flat embedded ultrathin sections of Caco-2 polarized cell monolayers (red asterisk: brush border; blue asterisk: tight junction); (D) Effect of free DNA solution, OA NPs or OHA NPs on the TEER values across Caco-2 cell monolayers. 


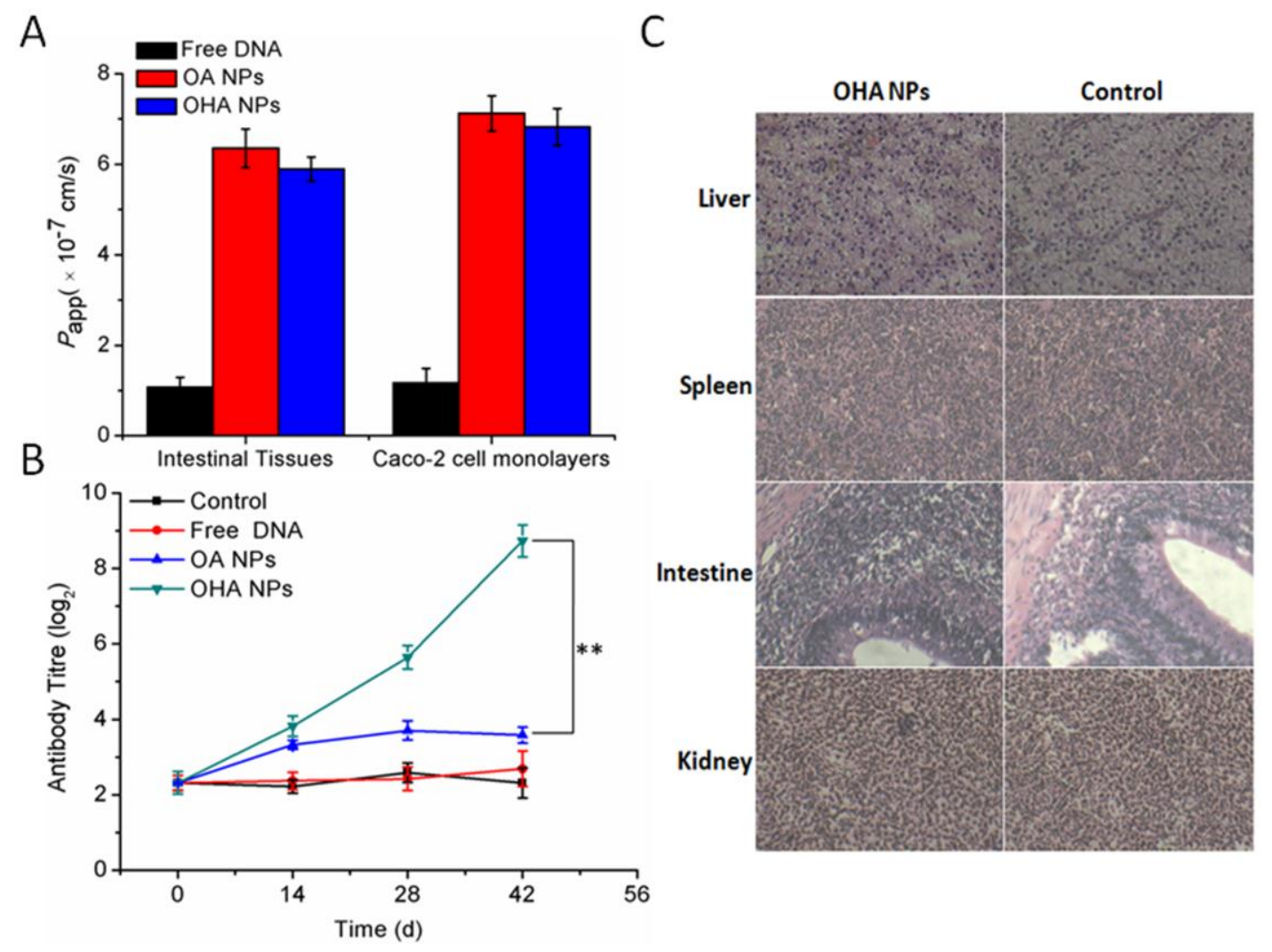

Figure 6. A). Apparent permeability coefficient $\left(P_{\text {app }}\right)$ of free DNA, OA NPs or OHA NPs through excised carp intestine and Caco-2 monolayer. B).Serum antibody titers in carps orally immunized with free DNA, OA NPs or OHA NPs. Data represented the mean $\pm \mathrm{SD}(\mathrm{n}=4)$. Asterisks $(*)$ denoted statistical significance; $*, \mathrm{P}<0.05 . \mathrm{C})$. Representative photomicrographs of the liver, spleen, intestine and kidney sections (H\&E staining) of carp orally treated with OHA NPs and control group. 


\section{Reference}

[1] M. Wonglapsuwan, P. Kongmee, N. Suanyuk, W. Chotigeat, Roles of phagocytosis activating protein (PAP) in Aeromonas hydrophila infected Cyprinus carpio, Developmental \& Comparative Immunology, 59 (2016) 25-33.

[2] D. Zhang, D.-H. Xu, C. Shoemaker, Experimental induction of motile Aeromonas septicemia in channel catfish (Ictalurus punctatus) by waterborne challenge with virulent Aeromonas hydrophila, Aquaculture Reports, 3 (2016) 18-23.

[3] Q. Zheng, Y. Wu, H. Xu, H. Wang, H. Tang, X. Xia, J. Feng, Immune responses to Aeromonas hydrophila infection in Schizothorax prenanti fed with oxidized konjac glucomannan and its acidolysis products, Fish \& Shellfish Immunology, 49 (2016) 260-267.

[4] M.S. Musthafa, A.R.J. Ali, M.J. Mohamed, M.M.A. Jaleel, M.S.A. Kumar, K.U. Rani, K. Vasanth, J. Arockiaraj, E. Preetham, C. Balasundaram, R. Harikrishnan, Protective efficacy of Azomite enriched diet in Oreochromis mossambicus against Aeromonas hydrophila, Aquaculture, 451 (2016) 310-315.

[5] G. SongLin, L. PanPan, F. JianJun, Z. JinPing, L. Peng, D. LiHua, A novel recombinant bivalent outer membrane protein of Vibrio vulnificus and Aeromonas hydrophila as a vaccine antigen of American eel (Anguilla rostrata), Fish \& Shellfish Immunology, 43 (2015) 477-484.

[6] J.-L. Wang, X.-l. Meng, R.-h. Lu, C. Wu, Y.-T. Luo, X. Yan, X.-J. Li, X.-H. Kong, G.-X. Nie, Effects of Rehmannia glutinosa on growth performance, immunological parameters and disease resistance to Aeromonas hydrophila in common carp (Cyprinus carpio L.), Aquaculture, 435 (2015) 293-300.

[7] L. Zhang, Z. Zeng, C. Hu, S.L. Bellis, W. Yang, Y. Su, X. Zhang, Y. Wu, Controlled and targeted release of antigens by intelligent shell for improving applicability of oral vaccines, Biomaterials, 77 (2016) 307-319.

[8] L.E. Ruff, E.A. Mahmoud, J. Sankaranarayanan, J.M. Morachis, C.D. Katayama, M. Corr, S.M. Hedrick, A. Almutairi, Antigen-loaded pH-sensitive hydrogel microparticles are taken up by dendritic cells with no requirement for targeting antibodies, Integrative Biology, 5 (2013) 195-203.

[9] A. Wack, R. Rappuoli, Vaccinology at the beginning of the 21st century, Current Opinion in Immunology, 17 (2005) 411-418.

[10] Z. Wang, P.J. Troilo, X. Wang, T.G. Griffiths, II, S.J. Pacchione, A.B. Barnum, L.B. Harper, C.J. Pauley, Z. Niu, L. Denisova, T.T. Follmer, G. Rizzuto, G. Ciliberto, E. Fattori, N.L. Monica, S. Manam, B.J. Ledwith, Detection of integration of plasmid DNA into host genomic DNA following intramuscular injection and electroporation, Gene Ther, 11 (2004) 711-721.

[11] K.P. Plant, S.E. LaPatra, Advances in fish vaccine delivery, Developmental \& Comparative Immunology, 35 (2011) 1256-1262.

[12] B.E. Brudeseth, R. Wiulsrød, B.N. Fredriksen, K. Lindmo, K.-E. Løkling, M. Bordevik, N. Steine, A. Klevan, K. Gravningen, Status and future perspectives of vaccines for industrialised fin-fish farming, Fish \& Shellfish Immunology, 35 (2013) 1759-1768.

[13] D.S. Silin, O.V. Lyubomska, V. Jirathitikal, A.S. Bourinbaiar, Oral vaccination: where we are?, Expert Opinion on Drug Delivery, 4 (2007) 323-340.

[14] L.-C. Cui, X.-T. Guan, Z.-M. Liu, C.-Y. Tian, Y.-G. Xu, Recombinant lactobacillus expressing G protein of spring viremia of carp virus (SVCV) combined with ORF81 protein of koi herpesvirus (KHV): A promising way to induce protective immunity against SVCV and KHV infection in cyprinid fish via oral vaccination, Vaccine, 33 (2015) 3092-3099.

[15] B. Ghosh, T.D. Nguyen, P.B.B. Crosbie, B.F. Nowak, A.R. Bridle, Oral vaccination of first-feeding Atlantic salmon, Salmo salar L., confers greater protection against yersiniosis than immersion vaccination, Vaccine, 34 (2016) 599-608.

[16] Y.-H. Kai, Y.-C. Wu, S.-C. Chi, Immune gene expressions in grouper larvae (Epinephelus coioides) induced by bath and oral vaccinations with inactivated betanodavirus, Fish \& Shellfish Immunology, 40 (2014) 563-569.

[17] J.L. Romalde, A. Luzardo-Alvárez, C. Ravelo, A.E. Toranzo, J. Blanco-Méndez, Oral immunization using alginate microparticles as a useful strategy for booster vaccination against fish lactoccocosis, Aquaculture, 236 (2004) 119-129.

[18] N.A. Ballesteros, S. Rodriguez Saint-Jean, S.I. Perez-Prieto, Immune responses to oral pcDNA-VP2 vaccine in relation to infectious pancreatic necrosis virus carrier state in rainbow trout Oncorhynchus mykiss, Veterinary Immunology and Immunopathology, 165 (2015) 127-137. 
[19] A.P. Rodrigues, D. Hirsch, H.C.P. Figueiredo, P.V.R. Logato, Â.M. Moraes, Production and characterisation of alginate microparticles incorporating Aeromonas hydrophila designed for fish oral vaccination, Process Biochemistry, 41 (2006) 638-643.

[20] N.H. Thinh, T.Y. Kuo, L.T. Hung, T.H. Loc, S.C. Chen, Ø. Evensen, H.J. Schuurman, Combined immersion and oral vaccination of Vietnamese catfish (Pangasianodon hypophthalmus) confers protection against mortality caused by Edwardsiella ictaluri, Fish \& Shellfish Immunology, 27 (2009) 773-776.

[21] N.A. Ballesteros, S.S.R. Saint-Jean, S.I. Perez-Prieto, J.M. Coll, Trout oral VP2 DNA vaccination mimics transcriptional responses occurring after infection with infectious pancreatic necrosis virus (IPNV), Fish \& Shellfish Immunology, 33 (2012) 1249-1257.

[22] C.J.H. Davitt, E.C. Lavelle, Delivery strategies to enhance oral vaccination against enteric infections, Advanced Drug Delivery Reviews, 91 (2015) 52-69.

[23] A. Mittal, K. Schulze, T. Ebensen, S. Weissmann, S. Hansen, C.A. Guzmán, C.-M. Lehr, Inverse micellar sugar glass (IMSG) nanoparticles for transfollicular vaccination, Journal of Controlled Release, 206 (2015) 140-152.

[24] F. Sarti, G. Perera, F. Hintzen, K. Kotti, V. Karageorgiou, O. Kammona, C. Kiparissides, A. Bernkop-Schnürch, In vivo evidence of oral vaccination with PLGA nanoparticles containing the immunostimulant monophosphoryl lipid A, Biomaterials, 32 (2011) 4052-4057.

[25] M. Garinot, V. Fiévez, V. Pourcelle, F. Stoffelbach, A. des Rieux, L. Plapied, I. Theate, H. Freichels, C. Jérôme, J. Marchand-Brynaert, Y.-J. Schneider, V. Préat, PEGylated PLGA-based nanoparticles targeting M cells for oral vaccination, Journal of Controlled Release, 120 (2007) 195-204.

[26] Y. Zhen, N. Wang, Z. Gao, X. Ma, B. Wei, Y. Deng, T. Wang, Multifunctional liposomes constituting microneedles induced robust systemic and mucosal immunoresponses against the loaded antigens via oral mucosal vaccination, Vaccine, 33 (2015) 4330-4340.

[27] Y. Liu, M. Kong, C. Feng, K.K. Yang, Y. Li, J. Su, X.J. Cheng, H.J. Park, X.G. Chen, Biocompatibility, cellular uptake and biodistribution of the polymeric amphiphilic nanoparticles as oral drug carriers, Colloids and Surfaces B: Biointerfaces, 103 (2013) 345-353.

[28] I.M. van der Lubben, J.C. Verhoef, A.C. van Aelst, G. Borchard, H.E. Junginger, Chitosan microparticles for oral vaccination:: preparation, characterization and preliminary in vivo uptake studies in murine Peyer's patches, Biomaterials, 22 (2001) 687-694.

[29] T. Jiang, B. Singh, H.-S. Li, Y.-K. Kim, S.-K. Kang, J.-W. Nah, Y.-J. Choi, C.-S. Cho, Targeted oral delivery of BmpB vaccine using porous PLGA microparticles coated with $\mathrm{M}$ cell homing peptide-coupled chitosan, Biomaterials, 35 (2014) 2365-2373.

[30] I.M. van der Lubben, G. Kersten, M.M. Fretz, C. Beuvery, J. Coos Verhoef, H.E. Junginger, Chitosan microparticles for mucosal vaccination against diphtheria: oral and nasal efficacy studies in mice, Vaccine, 21 (2003) 1400-1408.

[31] O. Borges, J. Tavares, A. de Sousa, G. Borchard, H.E. Junginger, A. Cordeiro-da-Silva, Evaluation of the immune response following a short oral vaccination schedule with hepatitis B antigen encapsulated into alginate-coated chitosan nanoparticles, European Journal of Pharmaceutical Sciences, 32 (2007) 278-290.

[32] Y. Liu, H. Di Zang, M. Kong, F.K. Ma, Q.F. Dang, X.J. Cheng, Q.X. Ji, X.G. Chen, In vitro evaluation of mucoadhesion and permeation enhancement of polymeric amphiphilic nanoparticles, Carbohydrate Polymers, 89 (2012) 453-460.

[33] F. Ventorp, R. Barzilay, S. Erhardt, M. Samuelsson, L. Träskman-Bendz, S. Janelidze, A. Weizman, D. Offen, L. Brundin, The CD44 ligand hyaluronic acid is elevated in the cerebrospinal fluid of suicide attempters and is associated with increased blood-brain barrier permeability, Journal of Affective Disorders, 193 (2016) 349-354.

[34] Y. Zhong, K. Goltsche, L. Cheng, F. Xie, F. Meng, C. Deng, Z. Zhong, R. Haag, Hyaluronic acid-shelled acid-activatable paclitaxel prodrug micelles effectively target and treat CD44-overexpressing human breast tumor xenografts in vivo, Biomaterials, 84 (2016) 250-261.

[35] X.-G. Chen, H.-J. Park, Chemical characteristics of O-carboxymethyl chitosans related to the preparation conditions, Carbohydrate Polymers, 53 (2003) 355-359.

[36] Y.Y. Li, X.G. Chen, C.S. Liu, D.S. Cha, H.J. Park, C.M. Lee, Effect of the Molecular Mass and Degree of Substitution of Oleoylchitosan on the Structure, Rheological Properties, and Formation of Nanoparticles, Journal of Agricultural and Food Chemistry, 55 (2007) 4842-4847.

[37] J. Gu, J. Hao, X. Fang, X. Sha, Factors influencing the transfection efficiency and cellular uptake mechanisms of Pluronic P123-modified polypropyleneimine/pDNA polyplexes in multidrug resistant breast cancer cells, Colloids and Surfaces B: Biointerfaces, 140 (2016) 83-93. 
[38] Z.-H. Li, P. Li, Z.-C. Shi, Molecular responses in digestive tract of juvenile common carp after chronic exposure to sublethal tributyltin, Ecotoxicology and Environmental Safety, 109 (2014) 10-14.

[39] S. He, X.-F. Liang, L. Li, J. Sun, D. Shen, Differential gut growth, gene expression and digestive enzyme activities in young grass carp (Ctenopharyngodon idella) fed with plant and animal diets, Aquaculture, 410-411 (2013) 18-24.

[40] T. Ostaszewska, K. Dabrowski, M. Kamaszewski, P. Grochowski, T. Verri, M. Rzepkowska, J. Wolnicki, The effect of plant protein-based diet supplemented with dipeptide or free amino acids on digestive tract morphology and PepT1 and PepT2 expressions in common carp (Cyprinus carpio L.), Comparative Biochemistry and Physiology Part A: Molecular \& Integrative Physiology, 157 (2010) 158-169.

[41] T. Irie, S. Watarai, T. Iwasaki, H. Kodama, Protection against experimental Aeromonas salmonicida infection in carp by oral immunisation with bacterial antigen entrapped liposomes, Fish \& Shellfish Immunology, 18 (2005) 235-242.

[42] Y. Liu, X.J. Cheng, Q.F. Dang, F.K. Ma, X.G. Chen, H.J. Park, B.K. Kim, Preparation and evaluation of oleoyl-carboxymethy-chitosan (OCMCS) nanoparticles as oral protein carriers, Journal of Materials Science: Materials in Medicine, 23 (2011) 375-384.

[43] M. Yu, S. Jambhrunkar, P. Thorn, J. Chen, W. Gu, C. Yu, Hyaluronic acid modified mesoporous silica nanoparticles for targeted drug delivery to CD44-overexpressing cancer cells, Nanoscale, 5 (2013) 178-183.

[44] T. An, C. Zhang, X. Han, G. Wan, D. Wang, Z. Yang, Y. Wang, L. Zhang, Y. Wang, Hyaluronic acid-coated poly([small beta]-amino) ester nanoparticles as carrier of doxorubicin for overcoming drug resistance in breast cancer cells, RSC Advances, 6 (2016) 38624-38636. 